Check for updates

Cite this: J. Mater. Chem. A, 2020, 8 18963

Received 21st May 2020

Accepted 7th July 2020

DOI: $10.1039 / \mathrm{d} 0 \operatorname{ta} 04844 \mathrm{e}$

rsc.li/materials-a

\title{
High entropy spinel oxide nanoparticles for superior lithiation-delithiation performance $\uparrow$
}

\author{
Thi Xuyen Nguyen, ${ }^{a}$ Jagabandhu Patra, (D) bc Jeng-Kuei Chang (iD)*b \\ and Jyh-Ming Ting (D)*a
}

High entropy spinel oxide (HESO) nanoparticles were synthesized via a surfactant-assisted hydrothermal method and used as a novel anode material in a lithium-ion battery. The HESO consists of nonequimolar cations of $\mathrm{Cr}, \mathrm{Mn}, \mathrm{Fe}, \mathrm{Co}$, and $\mathrm{Ni}$ dispersed in two Wyckoff sites with various valence states. Due to a strong entropy-induced phase stabilization effect of the $\mathrm{HESO}$, no inactive $\mathrm{MgO}$ structural pillars, which are exclusively present in the reported rock salt type high entropy oxides, are required to achieve high electrode cycling stability. A superior charge-discharge capacity of $1235 \mathrm{~mA} \mathrm{~h} \mathrm{~g}^{-1}$, the highest among all known HEOs, is obtained with 90\% capacity retention after 200 cycles. The unique $\mathrm{HESO}$ is also characterized by plenty of oxygen vacancies and three-dimensional $\mathrm{Li}^{+}$transport pathways. Also, great high-rate performance, i.e., $500 \mathrm{~mA} \mathrm{~h} \mathrm{~g}^{-1}$ a $2000 \mathrm{~mA} \mathrm{~g}^{-1}$, of the HESO electrode is demonstrated.

\section{Introduction}

Following the discovery of high entropy alloys more than a decade ago, ${ }^{1}$ the search for new, non-metallic high entropy stabilized materials has largely increased the interest in understanding this new category of advanced materials. Recent reports have shown several non-metallic high entropy stabilized materials, including high entropy oxides (HEOs), ${ }^{2-5}$ carbides, ${ }^{6,7}$ diborides, ${ }^{8,9}$ nitrides, ${ }^{10,11}$ and chalcogenides. ${ }^{12}$ Among these materials, HEOs are the most studied so far, although the knowledge about this type of material is still very limited. ${ }^{13}$ The pioneering paper on a HEO reported an equimolar fivecomponent rock-salt structure oxide, namely $\left(\mathrm{Mg}_{0.2} \mathrm{Co}_{0.2} \mathrm{Ni}_{0.2^{-}}\right.$ $\left.\mathrm{Cu}_{0.2} \mathrm{Zn}_{0.2}\right) \mathrm{O}$, and suggested that a compound having ionic characteristics is prone to exhibit an entropy stabilized structure. ${ }^{2}$ Following this study, several reports have demonstrated that high entropy stabilized oxides with five or more equimolar cations exhibit single-phase rock-salt, ${ }^{2,14-16}$ fluorite, ${ }^{17-19}$ spinel, ${ }^{20-23}$ and perovskite structures. ${ }^{3,4}$

One of the strategically important applications of HEOs is in lithium-ion batteries (LIBs). Rock-salt (MgCoNiCuZn) $)_{1-x-y} \mathrm{Ga}_{y^{-}}$ $\mathrm{A}_{x} \mathrm{O}$, with $\mathrm{A}=\mathrm{Li}, \mathrm{Na}$, or $\mathrm{K}$, showed extremely high roomtemperature $\mathrm{Li}^{+}$ion conductivity $\left(3 \times 10^{-3} \mathrm{~S} \mathrm{~cm}^{-1}\right)$ due to the

${ }^{a}$ Department of Materials Science and Engineering, National Cheng Kung University, 1 University Road, Tainan 70101, Taiwan.E-mail:jting@mail.ncku.edu.tw

${ }^{b}$ Department of Materials Science and Engineering, National Chiao Tung University, 1001 University Road, Hsinchu 30010, Taiwan. E-mail:jkchang@nctu.edu.tw ${ }^{c}$ Hierarchical Green-Energy Materials (Hi-GEM) Research Center, National Cheng Kung University, 1 University Road, Tainan 70101, Taiwan

$\dagger$ Electronic supplementary information (ESI) available. See DOI: 10.1039/d0ta04844e formation of oxygen vacancies. ${ }^{24} \mathrm{~A}$ rock-salt $\left(\mathrm{Mg}_{0.2} \mathrm{Co}_{0.2} \mathrm{Ni}_{0.2}\right.$ $\left.\mathrm{Cu}_{0.2} \mathrm{Zn}_{0.2}\right) \mathrm{O}$ anode showed much better cycling stability than the traditional conversion-type anodes owing to the high entropy stabilization effects of the HEO. ${ }^{25} \mathrm{~A}$ LIB full cell made of a $\left(\mathrm{Mg}_{0.2} \mathrm{Co}_{0.2} \mathrm{Ni}_{0.2} \mathrm{Cu}_{0.2} \mathrm{Zn}_{0.2}\right) \mathrm{O}$ anode and a layered-structure $\mathrm{LiNi}_{1 / 3} \mathrm{Co}_{1 / 3} \mathrm{Mn}_{1 / 3} \mathrm{O}_{2}$ cathode has been demonstrated to exhibit anode capacities of $446 \mathrm{~mA} \mathrm{~h} \mathrm{~g}{ }^{-1}$ in the first cycle and $256 \mathrm{~mA} \mathrm{~h} \mathrm{~g}^{-1}$ after 100 cycles. $^{26}$ This cell showed specific energy and power densities of $240 \mathrm{~W} \mathrm{~h} \mathrm{~kg}^{-1}$ and $320 \mathrm{~W} \mathrm{~kg}^{-1}$, respectively. Very recently, a multi-anionic and -cationic high entropy rock-salt oxyfluoride, i.e., $\mathrm{Li}_{x}\left(\mathrm{Mg}_{0.2} \mathrm{Co}_{0.2} \mathrm{Ni}_{0.2} \mathrm{Cu}_{0.2} \mathrm{Zn}_{0.2}\right) \mathrm{OF}_{x}$, was investigated as a LIB cathode material, showing an initial charge capacity of $168 \mathrm{~mA} \mathrm{~h} \mathrm{~g}{ }^{-1}$ at $\mathrm{C} / 20 .{ }^{27}$ Multiple anions were adopted in the multi-cationic compound for additional entropy stabilization. The HEO cathode has also been investigated for use in sodium-ion batteries (SIBs). ${ }^{28}$ The authors have demonstrated a layered $\mathrm{NaNi}_{0.12} \mathrm{Cu}_{0.12} \mathrm{Mg}_{0.12} \mathrm{Fe}_{0.15} \mathrm{Co}_{0.15} \mathrm{Mn}_{0.1} \mathrm{Ti}_{0.1}{ }^{-}$ $\mathrm{Sn}_{0.1} \mathrm{Sb}_{0.04} \mathrm{O}_{2}$ cathode for SIBs. The cathode exhibited approximately $83 \%$ capacity retention after 500 cycles and great rate capability at 5.0C.

Most of the HEO anodes for LIBs reported in the literature so far are equimolar $\mathrm{Mg} / \mathrm{Co} / \mathrm{Ni} / \mathrm{Cu} / \mathrm{Zn}$ exhibiting a rock-salt structure. ${ }^{15,25,26}$ Moreover, all the metals involved are divalent. The beauty of HEOs is the unlimited possibilities of having various or even novel functional properties, which can be realized by changing the HEO constituent elements, their concentrations, and the crystal structures. Similar to the rock-salt, fluorite, and perovskite type HEOs, high entropy spinel oxides (HESOs) have been recently explored. ${ }^{20-23}$ It is believed that HESOs are more promising due to the following reasons. The spinel structure is characterized by its unique three-dimensional $\mathrm{Li}^{+}$transport 
pathways. In contrast to a single cation Wyckoff site in rock-salt oxides, a spinel oxide, with a general formulation of $\mathrm{AB}_{2} \mathrm{O}_{4}$, has two different Wyckoff sites, i.e., A and B sites. This allows for the existence of tri-valence cations, which can increase the valence state variation range and thus the reversible capacity during the lithiation/delithiation process. Chen et al. have recently reported a spinel $\left(\mathrm{Mg}_{0.2} \mathrm{Ti}_{0.2} \mathrm{Zn}_{0.2} \mathrm{Cu}_{0.2} \mathrm{Fe}_{0.2}\right)_{3} \mathrm{O}_{4}$ anode for LIBs. The electrode delivered a reversible capacity of $504 \mathrm{~mA} \mathrm{~h} \mathrm{~g}^{-1}$ at a current density of $100 \mathrm{~mA} \mathrm{~g}^{-1}$ after 300 cycles and a rate capability of $272 \mathrm{~mA} \mathrm{~h} \mathrm{~g}^{-1}$ at $2000 \mathrm{~mA} \mathrm{~g}^{-1} \cdot{ }^{29}$

In this work, we demonstrate a non-equimolar design of a HESO based on multiple cations of $\mathrm{Cr}, \mathrm{Mn}, \mathrm{Fe}, \mathrm{Co}$, and $\mathrm{Ni}$. It is noted that there is no inactive, dummy $\mathrm{MgO}$ in the $\mathrm{HEO}$. MgO is used exclusively in rock-salt and spinel type HEOs to stabilize the structure and thus ensure the electrode cycling stability. The $\mathrm{Cr}, \mathrm{Mn}, \mathrm{Fe}, \mathrm{Co}$, and Ni cations are dispersed in the A and B sites of the spinel lattice, thus resulting in various valence states of the cations and plenty of oxygen vacancies. The oxygen vacancies can increase the configurational entropy and promote $\mathrm{Li}^{+}$ transport as well. ${ }^{24}$ HESO nanoparticles (NPs) are synthesized using a surfactant-assisted hydrothermal method. The resulting NPs have diameters in the range between 100 and $200 \mathrm{~nm}$. We demonstrate here that our HESO anode, with all the cations being electroactive, delivers an excellent capacity of $1235 \mathrm{~mA} \mathrm{~h} \mathrm{~g}^{-1}$, the highest among all the HEOs ever reported, and also high power capability and great cyclability.

\section{Experimental methods}

\section{HESO powder synthesis}

The HESO samples were synthesized using a surfactant-assisted hydrothermal method, in which the precursor salts were $\mathrm{Co}\left(\mathrm{NO}_{3}\right)_{2} \cdot 6 \mathrm{H}_{2} \mathrm{O}$ (J.T. Baker, 99\%), $\mathrm{Cr}\left(\mathrm{NO}_{3}\right)_{3} \cdot 9 \mathrm{H}_{2} \mathrm{O}$ (Alfa Aesar, 98.5\%), $\mathrm{Fe}\left(\mathrm{NO}_{3}\right)_{3} \cdot 9 \mathrm{H}_{2} \mathrm{O}$ (J.T. Baker, 99\%), $\mathrm{Mn}\left(\mathrm{NO}_{3}\right)_{2} \cdot 6 \mathrm{H}_{2} \mathrm{O}$ (Alfa Aesar, 98.5\%), and $\mathrm{Ni}\left(\mathrm{NO}_{3}\right)_{2} \cdot 6 \mathrm{H}_{2} \mathrm{O}$ (Alfa Aesar, 98.5\%), and the surfactant was (1-hexadecyl)trimethylammonium bromide (CTAB, Alfa Aesar, 98.5\%). The precursor solution was prepared by dissolving $\mathrm{Co}\left(\mathrm{NO}_{3}\right)_{2} \cdot 6 \mathrm{H}_{2} \mathrm{O}(2 \mathrm{mmol}), \mathrm{Cr}\left(\mathrm{NO}_{3}\right)_{3} \cdot 9 \mathrm{H}_{2} \mathrm{O}(0.75$ $\mathrm{mmol}), \mathrm{Fe}\left(\mathrm{NO}_{3}\right)_{3} \cdot 9 \mathrm{H}_{2} \mathrm{O}(0.5 \mathrm{mmol}), \mathrm{Mn}\left(\mathrm{NO}_{3}\right)_{2} \cdot 6 \mathrm{H}_{2} \mathrm{O}(2 \mathrm{mmol})$, and $\mathrm{Ni}\left(\mathrm{NO}_{3}\right)_{2} \cdot 6 \mathrm{H}_{2} \mathrm{O}(1 \mathrm{mmol})$ in $40 \mathrm{ml}$ of de-ionized (DI) water, followed by the addition of $1.25 \mathrm{ml}$ of CTAB. Urea was added when the solution became clear. The molar ratio of the urea to the total metal salts was $6: 1$. The resulting solution was then transferred into a $100 \mathrm{ml}$ Teflon-lined stainless-steel autoclave for hydrothermal treatment at $140{ }^{\circ} \mathrm{C}$ for $5 \mathrm{~h}$. After the hydrothermal treatment, the autoclave was cooled down to room temperature. The precipitates were collected from the obtained solution by centrifugation, washing (with ethanol and DI water), filtration, and then drying in a vacuum oven for $12 \mathrm{~h}$. The powdery sample was subsequently heat-treated in air at $900{ }^{\circ} \mathrm{C}$ for $2 \mathrm{~h}$ with a ramp of $10^{\circ} \mathrm{C} \mathrm{min}^{-1}$. Some selected samples were heat-treated at 300 and $600{ }^{\circ} \mathrm{C}$.

\section{Electrode preparation}

To prepare the active electrode, a slurry, made out of $70 \mathrm{wt} \%$ HESO powder, 20 wt $\%$ carbon black, and 10 wt $\%$ poly(vinylidene fluoride) binder in $N$-methyl-2-pyrrolidone solution, was pasted onto a piece of $\mathrm{Cu}$ foil using a doctor blade. This electrode was vacuum-dried at $90{ }^{\circ} \mathrm{C}$ for $6 \mathrm{~h}$, rollpressed, and then punched to match the required dimensions of a CR2032 coin cell. The active material loading was $1.5( \pm 0.1) \mathrm{mg} \mathrm{cm} \mathrm{cm}^{-2}$. Lithium foil and a glass fiber membrane were used as the counter electrode and separator, respectively. The electrolyte was composed of $1 \mathrm{M} \mathrm{LiPF}_{6}$ salt and a mixed solvent of ethylene carbonate and diethyl carbonate $(1: 1$ by volume). Assembly of the coin cells was conducted in an argonfilled glove box (Innovation Technology Co. Ltd.), where both the moisture and oxygen content levels were maintained at below 0.5 ppm.

\section{Materials characterization}

The crystalline structure of the HESO NPs was examined using an X-ray diffractometer (XRD, Rigaku) with a $\mathrm{Cu} \mathrm{K} \alpha$ radiation source. The diffraction angle was scanned from 10 to $90^{\circ}$ with a speed of $2^{\circ} \mathrm{min}^{-1}$. Scanning electron microscopy (SEM, JEOL $6701 \mathrm{~F}$ ) was used to examine the morphology. Transmission electron microscopy (TEM, JEOL JEM-2100F) equipped with selected area electron diffractometry (SAED) and energydispersive X-ray spectroscopy (EDS) was used to analyze the microstructure and chemical composition. The surface chemistry was investigated using X-ray photoelectron spectroscopy (XPS, Versaprobe PHI 5000). Inductively coupled plasma-mass spectrometry (ICP-MS, Thermo-Element XR) was used to examine the chemical composition of the samples.

\section{Electrochemical property measurements}

Cyclic voltammetry (CV) was performed using a Biologic VSP300 potentiostat between 0.01 and $3.0 \mathrm{~V}$ with a potential sweep rate of $0.1 \mathrm{mV} \mathrm{s}^{-1}$. Electrochemical impedance spectroscopy (EIS) measurement was conducted in the frequency range of $100 \mathrm{kHz}$ to $10 \mathrm{MHz}$ and with an AC amplitude of $10 \mathrm{mV}$. The charge-discharge properties, such as capacity, rate capability, and cycling stability, of the cells were evaluated using a battery tester (Arbin, BT-2043) at $25{ }^{\circ} \mathrm{C}$. The postmortem analyses on the electrode material were also carried out. The cycled electrode was taken out of the cell inside the glovebox, washed with dimethyl carbonate solvent, and then vacuum dried. Afterward, the sample was subjected to SEM, TEM, and XPS characterization. Ex situ XRD analysis was performed to examine the lithiation/delithiation mechanism. For these measurements, the electrodes were charged/discharged at a rate of $75 \mathrm{~mA} \mathrm{~g}^{-1}$ to various states, at which the electrode potential was held for $6 \mathrm{~h}$. The cells were then disassembled inside the glovebox, and the active materials were detached from the $\mathrm{Cu}$ foil and subjected to XRD analysis.

\section{Results and discussion}

\section{Materials characterization}

The morphology of the obtained HESO powder was first examined using SEM. The sample subjected to heat treatment at $900{ }^{\circ} \mathrm{C}$ was found to be NPs, as shown in Fig. 1a. The NPs exhibit 

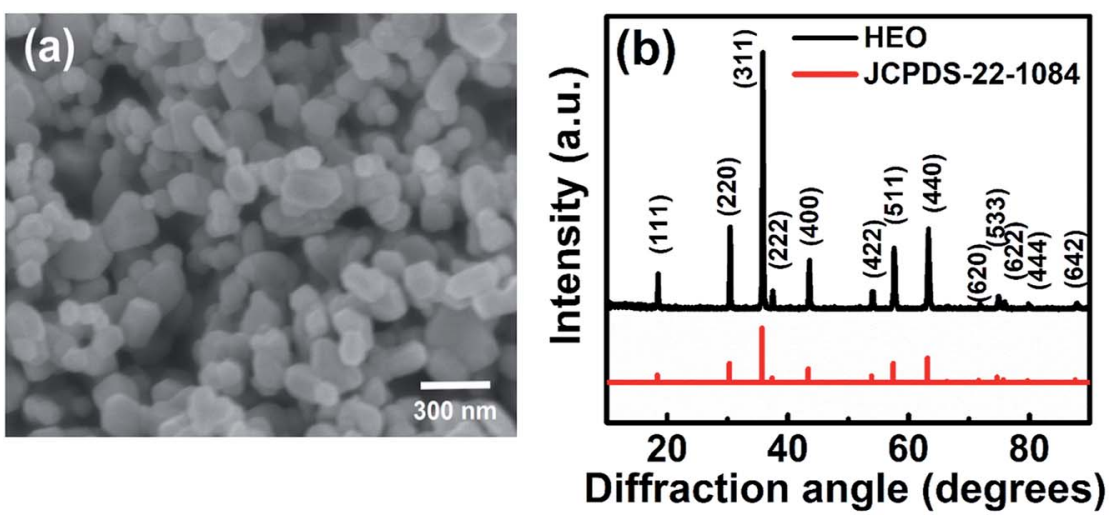

Fig. 1 (a) SEM image and (b) XRD pattern of HESO NPs.

a uniform size distribution, ranging from 100 to $200 \mathrm{~nm}$. On the other hand, the as-synthesized sample, i.e., without any heat treatment, consists of sub-micro-sized agglomerates of NPs, as shown in Fig. S1a. $\dagger$ The agglomerates break up with increasing the heat-treatment temperature, as shown in Fig. S1b, S1c, and $\mathrm{S} 1 \mathrm{~d}, \dagger$ for samples obtained after heat treatment at 300, 600, and $900{ }^{\circ} \mathrm{C}$, respectively. In other words, after heat treatment at $900{ }^{\circ} \mathrm{C}$, the HESO NPs form, as shown in Fig. 1a. The use of NPs
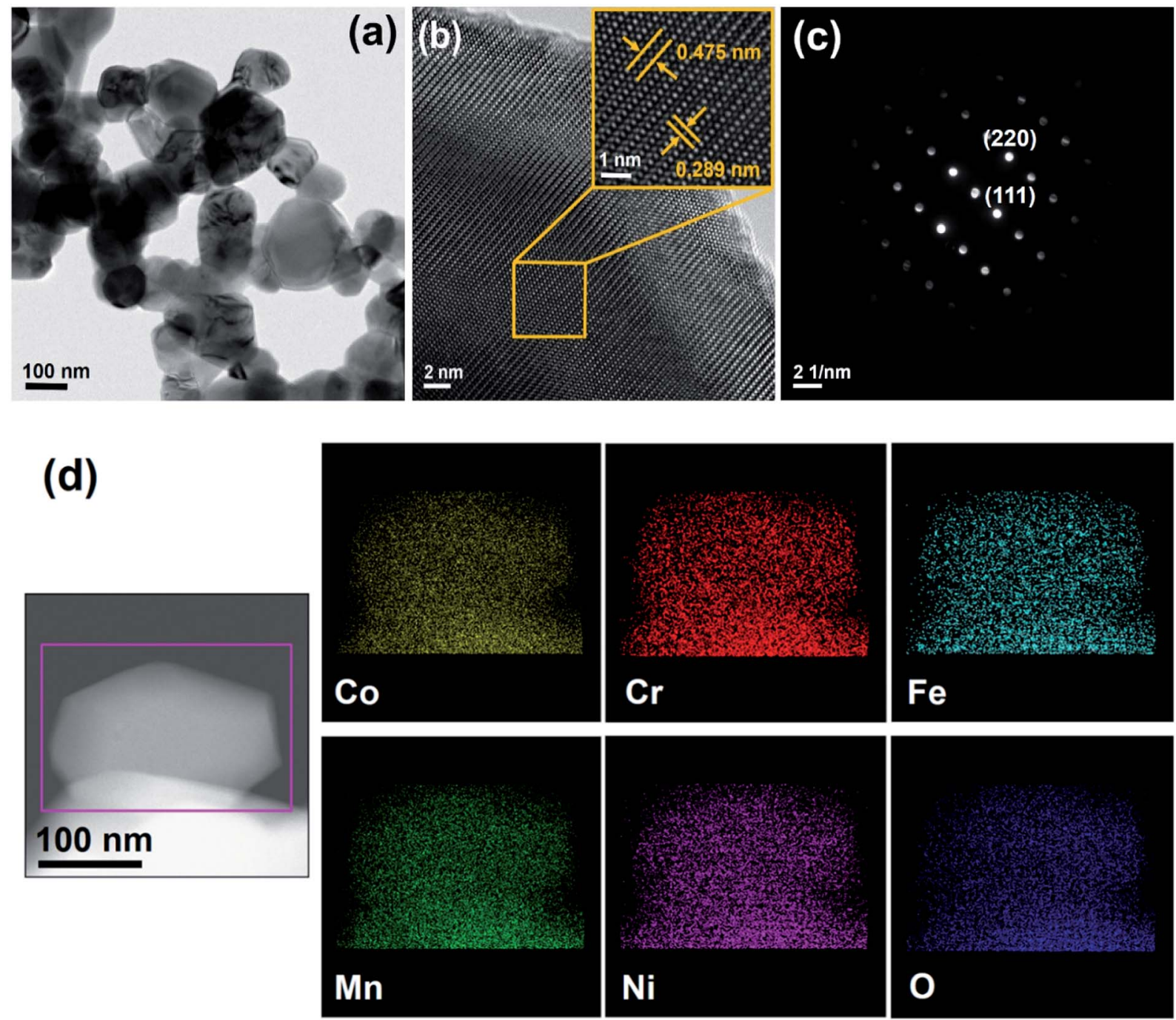

Fig. 2 (a) TEM, (b) HRTEM, (c) SAED, and (d) STEM mapping data of HESO NPs. 
to make LIB electrodes provides more active sites for charge storage, and is expected to give a high capacity, high rate capability, and good reversibility. ${ }^{30,31}$ The XRD patterns of the samples obtained without heat treatment and with heat treatment at various temperatures exhibit different crystalline phases, as shown in Fig. S2.† The major phases of the assynthesized sample are metal hydroxycarbonate, with or without $\mathrm{H}_{2} \mathrm{O}$, and metal carbonate. After the $300{ }^{\circ} \mathrm{C}$ heat treatment, the metal hydroxycarbonates disappeared but oxides were found. In the meantime, the metal carbonates remained. After the $600{ }^{\circ} \mathrm{C}$ heat treatment, three prominent crystalline structures were observed due to the appearance of spinel, rocksalt, and hexagonal structures. After the heat treatment at $900{ }^{\circ} \mathrm{C}$, the sample became a single-phase cubic spinel of the $F d \overline{3} m$ space group (JCPDS no. 22-1084). The lattice constant determined from the XRD pattern in Fig. $1 \mathrm{~b}$ is $8.315 \AA$. The obtained NPs were further investigated using TEM (Fig. 2a). An HRTEM image of a NP is shown in Fig. 2b, where the (111) and (220) diffraction planes with $d$ spacings of 0.475 and $0.289 \mathrm{~nm}$, respectively, are seen. The corresponding SAED pattern is given in Fig. 2c, confirming the formation of a single-phase cubic spinel structure with high crystallinity. The TEM-EDS analysis shows that the cations distribute homogeneously across the NPs (Fig. 2d). ICP-MS was also performed to examine the chemical composition of the sample. The elemental concentrations obtained from the ICP-MS analysis match those of the precursors. The elemental concentrations in the precursor solution are 29.6, 11.1, 7.4, 29.6, and $22.2 \%$ for $\mathrm{Co}, \mathrm{Cr}, \mathrm{Fe}, \mathrm{Mn}$, and $\mathrm{Ni}$; while those obtained from the ICP-MS analysis of the NPs are $30.2,11.2,8.0,28.6$, and $22.0 \%$, respectively. This
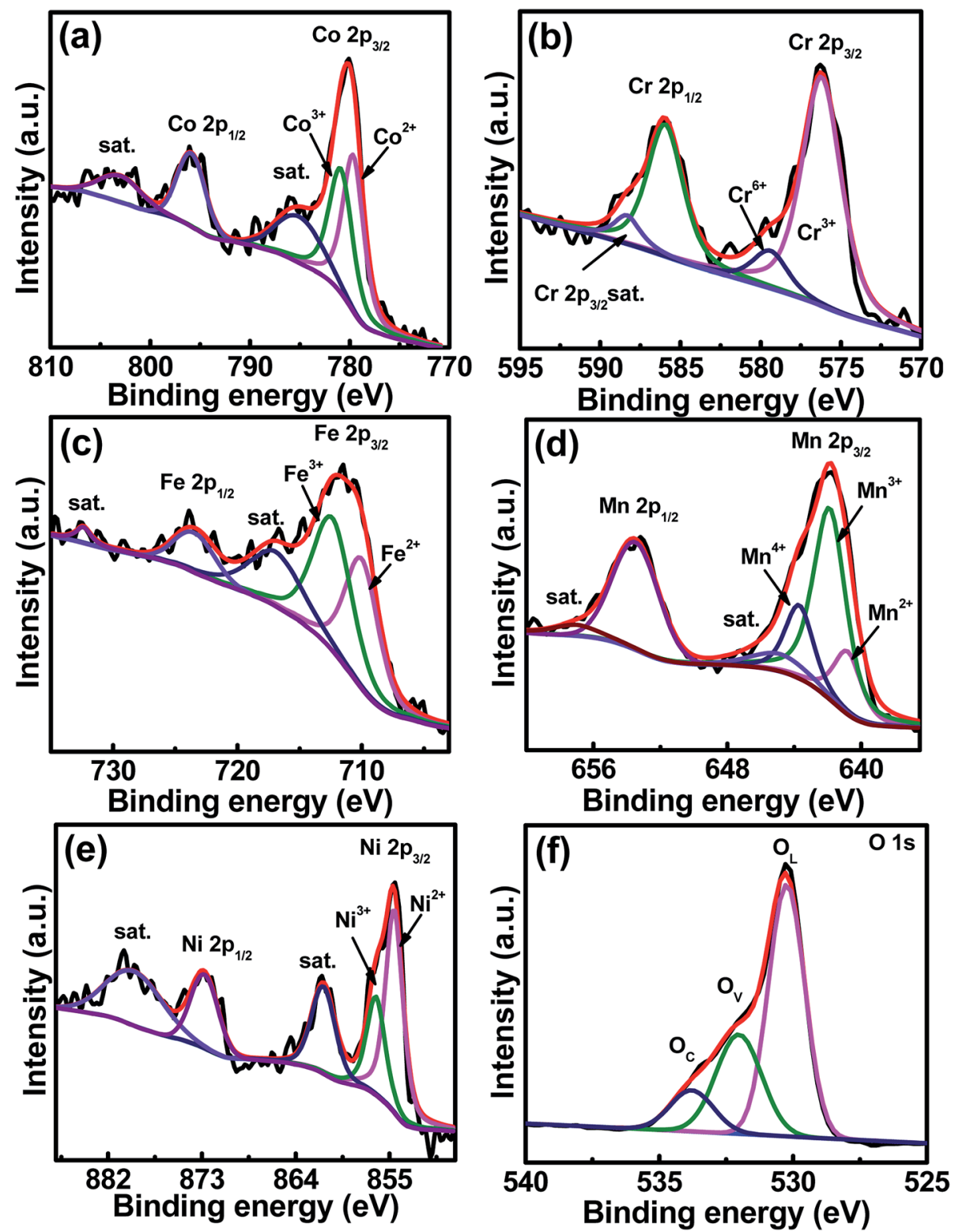

Fig. 3 XPS (a) Co 2p, (b) Cr 2p, (c) Fe 2p, (d) Mn 2p, (e) Ni 2p, and (f) O 1s spectra of HESO NPs. 
suggests that essentially all the elements remain in the final product of HESO NPs. From the ICP-MS data, the configurational entropy was determined to be $1.5 R$ using the Boltzmann equation..$^{15,32}$

The core-level XPS spectra of Co 2p, Cr 2p, Fe 2p, Mn 2p, Ni $2 \mathrm{p}$, and $\mathrm{O} 1 \mathrm{~s}$ of the sample are shown in Fig. 3a-f, respectively. The Co 2p spectrum shows two major peaks at 780.1 and $796.2 \mathrm{eV}$, corresponding to Co $2 \mathrm{p}_{3 / 2}$ and Co $2 \mathrm{p}_{1 / 2}$ binding energies, respectively. ${ }^{33,34}$ Two satellite peaks are at 785.4 and $802.9 \mathrm{eV}{ }^{35}$ The spectrum shows co-existence of $\mathrm{Co}^{2+}$ and $\mathrm{Co}^{3+}$, and the $\mathrm{Co}^{2+} / \mathrm{Co}^{3+}$ concentration ratio is $46.9 / 53.1$. In the $\mathrm{Cr} 2 \mathrm{p}_{3} /$ 2 spectrum, $\mathrm{Cr}^{3+}$ and $\mathrm{Cr}^{6+}$ are seen at 576.2 and $579.2 \mathrm{eV}$, respectively, ${ }^{36}$ and $\mathrm{Cr}^{3+}$ dominates with a concentration of $87.2 \%$, balanced by $\mathrm{Cr}^{6+}$. The peak at a binding energy of $586.2 \mathrm{eV}$ represents the $\mathrm{Cr} 2 \mathrm{p}_{1 / 2}$ signal. $^{34,37}$ The satellite peak of Cr $2 \mathrm{p}_{3 / 2}$ is at $587.7 \mathrm{eV}$, while the satellite peak of $\mathrm{Cr} 2 \mathrm{p}_{1 / 2}$ locates in between 598 and $600 \mathrm{eV},{ }^{37,38}$ which is out of the scan range used in this study. In the Fe 2 p spectrum, two peaks are seen at 711.5 and $723.7 \mathrm{eV}$, which are attributed to the spin-orbit peaks of $\mathrm{Fe} 2 \mathrm{p}_{3 / 2}$ and $\mathrm{Fe} 2 \mathrm{p}_{1 / 2}$, respectively. ${ }^{39}$ The $\mathrm{Fe}^{2+} / \mathrm{Fe}^{3+}$ ratio is 45.3/54.7. Two satellite peaks belonging to $\mathrm{Fe} 2 \mathrm{p}_{3 / 2}$ and $\mathrm{Fe} 2 \mathrm{p}_{1 / 2}$ are at 718.1 and $732.2 \mathrm{eV}$, respectively. The $\mathrm{Mn} 2 \mathrm{p}_{3 / 2}$ spectrum is centered at $642.5 \mathrm{eV}$, which can be deconvoluted into $\mathrm{Mn}^{2+}$ at $640.4 \mathrm{eV}(17.8 \%), \mathrm{Mn}^{3+}$ at $641.8 \mathrm{eV}$ (61.6\%), and $\mathrm{Mn}^{4+}$ at $643.6 \mathrm{eV}(20.6 \%){ }^{34,36,40}$ The peaks at 646.1 and $658.0 \mathrm{eV}$ are the satellite peaks of $\mathrm{Mn} 2 \mathrm{p}_{3 / 2}$ and Mn $2 \mathrm{p}_{1 / 2}$, respectively. ${ }^{41}$ The $\mathrm{Mn}$ $2 \mathrm{p}_{1 / 2}$ peak locates at a binding energy of $653.08 \mathrm{eV} .{ }^{34}$ The highresolution XPS spectrum of Ni shows two spin-orbit peaks at
855.2 and $872.3 \mathrm{eV}$, which can be ascribed to $\mathrm{Ni} 2 \mathrm{p}_{3 / 2}$ and $\mathrm{Ni} 2 \mathrm{p}_{1 /}$ 2 , respectively. Deconvolution of $\mathrm{Ni} 2 \mathrm{p}_{3 / 2}$ shows two peaks at different energies. The peak at $854.4 \mathrm{eV}$ is ascribed to $\mathrm{Ni}^{2+}$, having a concentration of $66.3 \%$, while the other peak at 856.0 eV corresponds to $\mathrm{Ni}^{3+},{ }^{42}$ having a concentration of $32.7 \%$. Two satellite peaks were detected at the high-binding-energy side around $861.3\left(\mathrm{Ni} 2 \mathrm{p}_{3 / 2}\right)$ and $879.8\left(\mathrm{Ni} 2 \mathrm{p}_{1 / 2}\right) \mathrm{eV}$. The $\mathrm{O} 1 \mathrm{~s}$ spectrum can be deconvoluted into three peaks at 530.1, 531.6, and $533.7 \mathrm{eV}$, which are assigned to the lattice oxygen $\mathrm{O}_{\mathrm{L}}$, oxygen vacancies $\mathrm{O}_{\mathrm{V}}$, and chemisorbed oxygen $\mathrm{O}_{\mathrm{C}}$, respectively. ${ }^{43-46}$ The $\mathrm{O}_{\mathrm{L}} / \mathrm{O}_{\mathrm{V}} / \mathrm{O}_{\mathrm{C}}$ ratio was determined to be $59.2 / 29.3 /$ 11.5. The existence of high-valence $\mathrm{Cr}^{6+}$ and $\mathrm{Mn}^{4+}$ in the prepared HESO is attributed to the surface oxidation that could happen during the $900{ }^{\circ} \mathrm{C}$ heat treatment in air. We think that these species only exist on the sample surface because they were not detected in the XRD and TEM analyses.

\section{Formation mechanism}

As mentioned above, to synthesize the HESO NPs, CTAB was used as the surfactant, which serves as an efficient soft colloidal template for controlling the size and shape of the NPs. ${ }^{47}$ Prior to the hydrothermal synthesis, CTAB forms $\mathrm{CTA}^{+}$and $\mathrm{Br}^{-}$in the solution and hydrolysis of urea takes place according to Reactions (1)-(3). ${ }^{48}$ Subsequently, during the hydrothermal process, metal hydroxycarbonates and carbonates form according to Reactions (4) and (5). After the heat treatment at $900{ }^{\circ} \mathrm{C}$, spinel oxide forms, as shown in Reaction (6). ${ }^{48}$
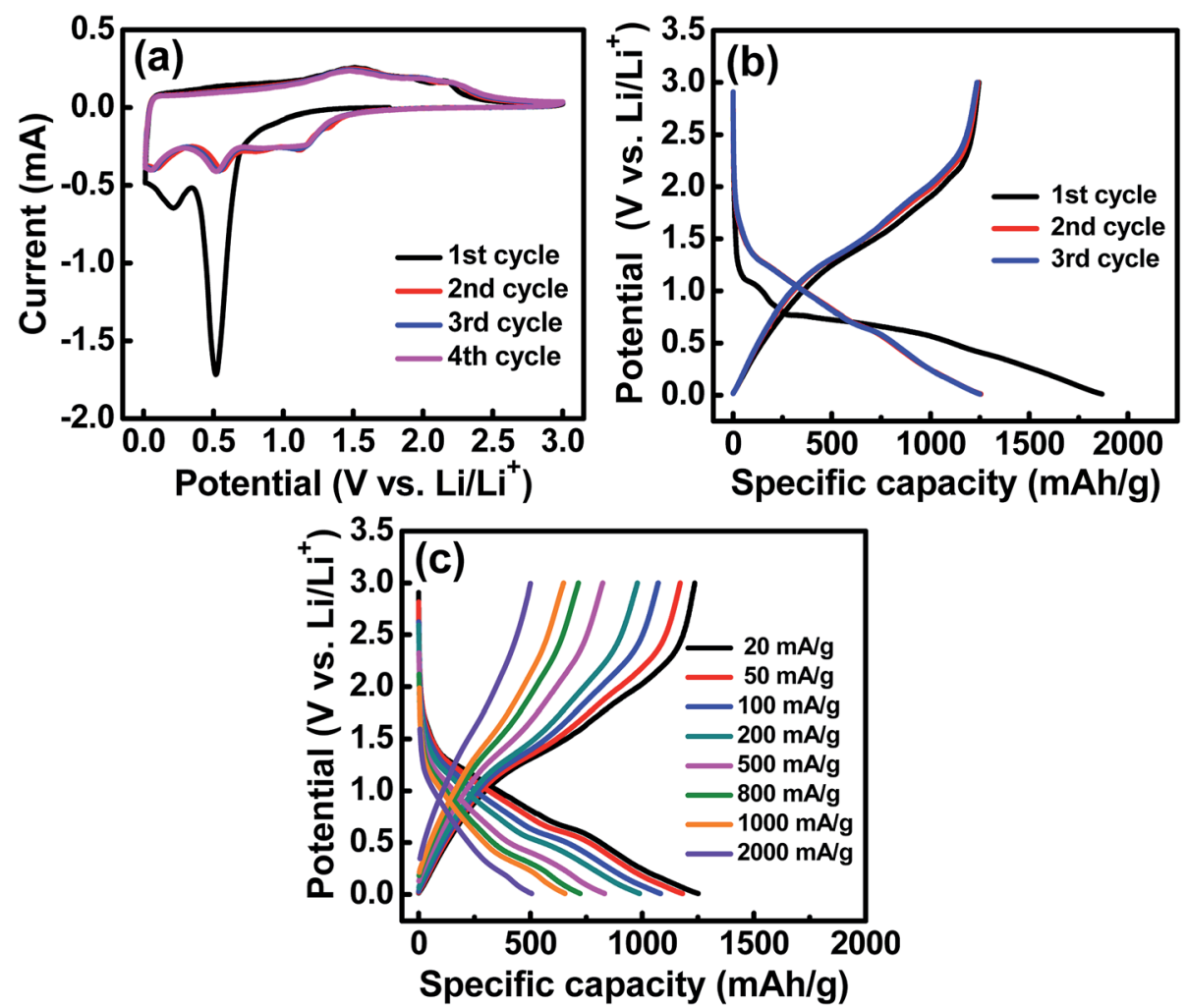

Fig. 4 (a) CV curves of the HESO electrode measured at a potential sweep rate of $0.1 \mathrm{mV} \mathrm{s}^{-1}$. (b) Initial three galvanostatic charge-discharge curves of the HESO electrode measured at $20 \mathrm{~mA} \mathrm{~g}^{-1}$. (c) Charge-discharge curves of the HESO electrode measured at various rates. 


$$
\begin{gathered}
\mathrm{CO}\left(\mathrm{NH}_{2}\right)_{2}+\mathrm{H}_{2} \mathrm{O} \rightarrow 2 \mathrm{NH}_{3}+\mathrm{CO}_{2} \\
\mathrm{CO}_{2}+\mathrm{H}_{2} \mathrm{O} \rightarrow \mathrm{CO}_{3}{ }^{2-}+2 \mathrm{H}^{+} \\
\mathrm{NH}_{3}+\mathrm{H}_{2} \mathrm{O} \rightarrow \mathrm{NH}_{4}^{+}+\mathrm{OH}^{-} \\
\mathrm{M}^{x+}+y \mathrm{CO}_{3}^{2-}+x \mathrm{OH}^{-} \rightarrow \mathrm{M}(\mathrm{OH})_{x} \cdot\left(\mathrm{CO}_{3}\right)_{y} \\
\mathrm{M}^{2+}+\mathrm{CO}_{3}^{2-} \rightarrow \mathrm{M}\left(\mathrm{CO}_{3}\right) \\
\mathrm{M}(\mathrm{OH})_{x}\left(\mathrm{CO}_{3}\right)_{y}, \mathrm{M}\left(\mathrm{CO}_{3}\right) \stackrel{\Delta}{\longrightarrow} \mathrm{M}_{3} \mathrm{O}_{4}+\mathrm{H}_{2} \mathrm{O}+\mathrm{CO}_{2} \\
(\mathrm{M}=\mathrm{Co}, \mathrm{Cr}, \mathrm{Fe}, \mathrm{Mn} \text {, and Ni). } \\
\text { The formation of spinel NPs is further described in Fig. S3. } \dagger
\end{gathered}
$$

\section{Electrochemical performance}

The electrochemical characteristics of the HESO anode were examined using $\mathrm{CV}$. The obtained curves with multiple anodic and cathodic peaks, which are associated with $\mathrm{Li}^{+}$insertion/ extraction for the HESO, are shown in Fig. 4a. In the first negative (lithiation) scan, a huge irreversible peak at $\sim 0.5 \mathrm{~V}$ is seen. This can be ascribed to electrolyte decomposition and solid electrolyte interphase (SEI) formation together with some conversion reactions of the electrode. ${ }^{49,50}$ Afterward, another cathodic peak located at below $0.3 \mathrm{~V}$ emerges, indicating a further reduction of the HESO components at lower potentials. In the following positive scan, the anodic current before $\sim 1.2 \mathrm{~V}$ is steady, suggesting that the electrode delithiation rate was almost constant. There are multiple overlapped oxidation peaks in the potential region between 1.2 and $2.5 \mathrm{~V}$, which are related to re-oxidation and/or re-conversion of the reduced species produced during the lithiation process. $^{51,52}$ In the second cycle, the lithiation reactions are facilitated to launch at $\sim 1.5 \mathrm{~V}$. It is noted that from the second cycle onward, the subsequent CV curves basically overlap, indicating good electrochemical reversibility and stability of the $\mathrm{Li}^{+}$insertion/ extraction reactions of the HESO electrode. Previously reported rock-salt (MgCoNiCuZn)O needs inactive MgO to stabilize the cycling charge-discharge performance. ${ }^{25}$ However, we have demonstrated that the spinel $(\mathrm{MnFeCoNiCr})_{3} \mathrm{O}_{4}$, with all the cations being electroactive within the potential range, provides great redox stability.

Fig. 5 shows a series of $e x$ situ XRD patterns of the HESO electrode recorded after being charged/discharged to various potentials. At a lithiation potential of $0.8 \mathrm{~V}$, the spinel structure was still intact since no significant $\mathrm{Li}^{+}$uptake reaction had occurred (see Fig. 4a). When the electrode was lithiated to $0.5 \mathrm{~V}$, the major peak at $35.7^{\circ}$ clearly diminished. Phase transformation to a rock-salt type oxide, having a major peak at $43.1^{\circ}$, was recognized. The diffraction signals around $31^{\circ}$ to $33^{\circ}$ are identified to be hexagonal $\mathrm{M}_{2} \mathrm{O}_{3}\left(\mathrm{H}-\mathrm{M}_{2} \mathrm{O}_{3}\right.$; JCPDS no. 40-1139) ( $\mathrm{M}$ may include $\mathrm{Mn}, \mathrm{Fe}, \mathrm{Co}, \mathrm{Ni}$, and $\mathrm{Cr}$ ). Moreover, the peak at $33.6^{\circ}$ is ascribed to $\mathrm{Li}_{2} \mathrm{O}$ (JCPDS no. 12-0254), which shows that HESO conversion reactions have taken place. The small peaks at $\sim 21.6^{\circ}$ and $\sim 23.6^{\circ}$ cannot be exactly identified at the current stage. Further study on the lithiation products would require the use of synchrotron X-ray radiation to obtain stronger

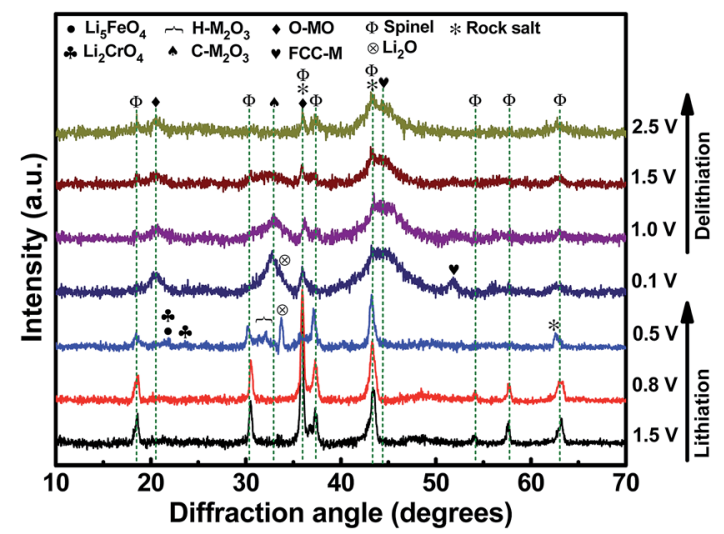

Fig. 5 Ex situ XRD patterns of HESO electrodes charged/discharged to various potentials.

diffraction intensity. At $0.1 \mathrm{~V}$, when the lithiation degree was further increased, the $\mathrm{H}-\mathrm{M}_{2} \mathrm{O}_{3}$ phase disappeared, whereas several new diffraction peaks showed up. In addition to the facecentered cubic metallic phase (FCC-M; JCPDS no. 15-0806), orthorhombic MO (O-MO; JCPDS no. 04-0326) and cubic $\mathrm{M}_{2} \mathrm{O}_{3}$ (C- $\mathrm{M}_{2} \mathrm{O}_{3}$; JCPDS no. 39-0238) were seen, indicating a reductive reconstruction of the HESO. It is noted that the rock-salt phase remained at such a low potential. We believe that this is crucial for the electrode cycling stability, discussed in detail later. When the electrode was delithiated up to $2.5 \mathrm{~V}$, with the rocksalt phase in the material, the $\mathrm{O}-\mathrm{MO}$ and $\mathrm{C}-\mathrm{M}_{2} \mathrm{O}_{3}$ phases continuously reduced. Meanwhile, the HESO phase was partially recovered, which can be supported by the reappearance of the spinel (111) peak at $18.4^{\circ}$ and the (222) peak at $37.4^{\circ}$. The recovery of the spinel phase is interesting and different from the XRD results reported for the rock-salt type HEO in the literature..$^{15}$ For the conventional conversion-type anodes, the crystalline oxide phases are severely distorted and usually become nearly amorphous after the first chargedischarge cycle..$^{53-55}$ However, a partial phase recovery is demonstrated here, which is responsible for the great electrode reversibility shown in the CV data. Also, the delithiation XRD patterns show that the FCC-M phase remains at $2.5 \mathrm{~V}$. Basically, metallic phases are not stable and tend to oxidize at such a high potential. ${ }^{56,57}$ We believe that the entropy-dominated phasestabilization effect plays a vital role., ${ }^{2,13}$ The multi-component HESO structure, together with the existence of oxygen vacancies, stabilizes the metallic phase. The co-existence of rock-salt and spinel phases after the first charge-discharge cycle is also supported by the high-resolution TEM and electron diffraction data, as shown in Fig. 6. The lattice spacings corresponding to the (111) and (311) planes of the HESO together with a distinct diffraction pattern are seen. In the same particle, the (111) and (200) planes of the rock-salt phase are also observed. Importantly, the recovery of the crystalline spinel phase is unique. The high entropy brings about a benefit of lowering the Gibbs free energy ${ }^{15,58,59}$ which facilitates the regeneration of the HESO. TEM-EDS analysis was performed on the sample after one charge-discharge cycle. There is no apparent change in the 

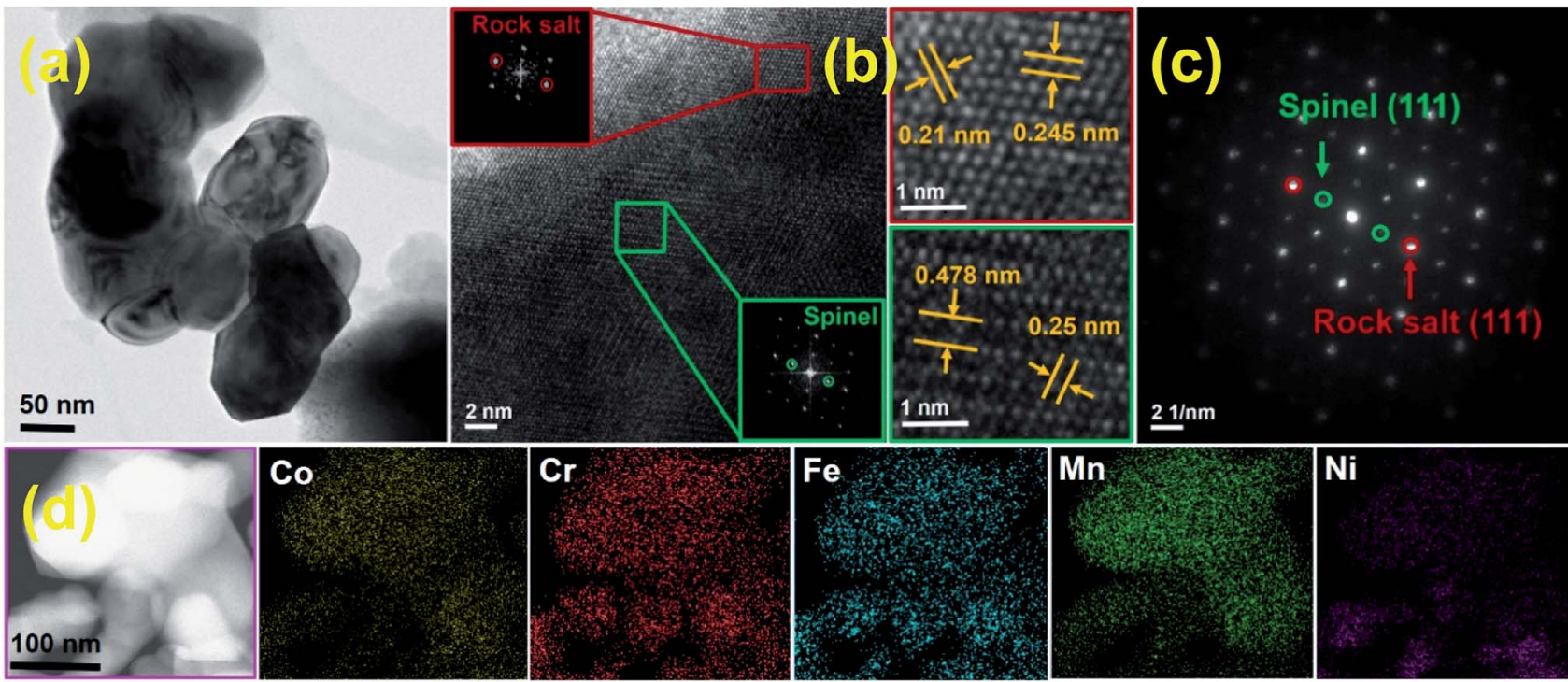

Fig. 6 (a) TEM, (b) HRTEM, (c) SAED, and (d) STEM mapping data of HESO NPs after the first charge-discharge cycle.

elemental distribution, as shown in Fig. 6, confirming that the electrode material is still in a high entropy state.

Three initial galvanostatic charge-discharge curves measured at $20 \mathrm{~mA} \mathrm{~g}^{-1}$ and various rates are shown in Fig. $4 \mathrm{~b}$ and c, respectively. As shown in Fig. 4b, the first lithiation curve is characterized by a potential plateau at $\sim 0.5 \mathrm{~V}$, which is consistent with the CV result (see Fig. 4a) and is associated with the SEI formation and some $\mathrm{Li}^{+}$uptake reactions. The lithiation and delithiation capacities are 1869 and $1245 \mathrm{~mA} \mathrm{~h} \mathrm{~g}{ }^{-1}$, respectively, corresponding to a first-cycle coulombic efficiency
(CE) of $\sim 67 \%$. We believe that this value can be further improved by using an electrode binder and electrolyte recipe optimization and by the use of a suitable surface coating on the HESO NPs. In the subsequent cycles, the reversible capacities are stable at $\sim 1235 \mathrm{~mA} \mathrm{~h} \mathrm{~g}{ }^{-1}$, with the CE being above $99 \%$. Fig. 4c shows the charge-discharge curves of the HESO electrode acquired at various current densities ranging from 20 to $2000 \mathrm{~mA} \mathrm{~g}^{-1}$. The measured delithiation capacities are 1170 , $1072,979,824,715$, and $649 \mathrm{~mA} \mathrm{~h} \mathrm{~g}^{-1}$ at 50, 100, 200, 500, 800, and $1000 \mathrm{~mA} \mathrm{~g}^{-1}$, respectively. Even at a high rate of
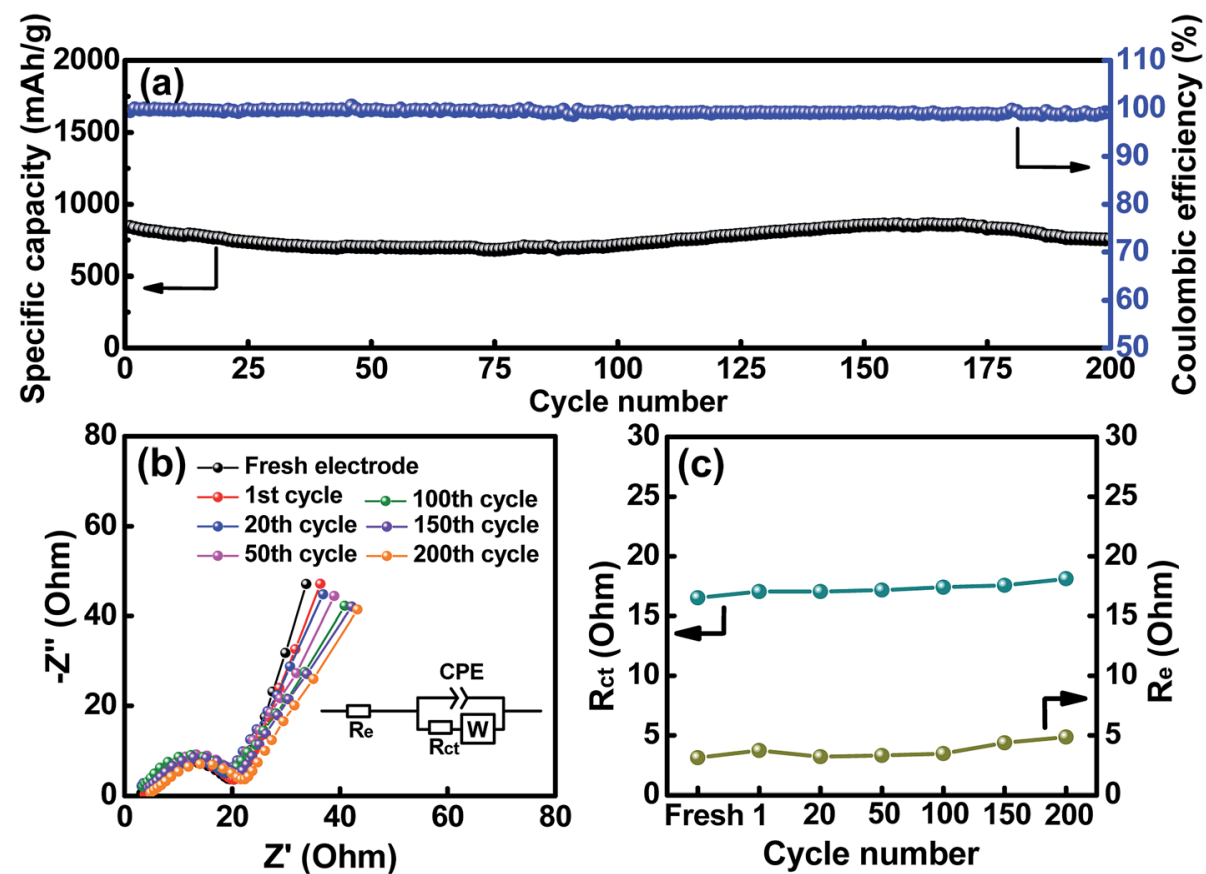

Fig. 7 (a) Cycling stability of the HESO electrode. (b) EIS spectra and (c) the obtained $R_{\mathrm{e}}$ and $R_{\mathrm{ct}}$ values of the HESO electrode measured after various charge-discharge cycles. 
$2000 \mathrm{~mA} \mathrm{~g}^{-1}$, the electrode still can deliver a superior capacity of $500 \mathrm{~mA} \mathrm{~h} \mathrm{~g}{ }^{-1}$. In general, conversion-type oxide anodes show a significant capacity deterioration at high current rates due to their low electronic conductivity and kinetic limitations of diffusion-driven redox processes during charging/discharging. ${ }^{60,61}$ In the literature, CNT@CuO delivered $\sim 275 \mathrm{~mA} \mathrm{~h} \mathrm{~g}^{-1}$ @ $1340 \mathrm{~mA} \mathrm{~g}^{-1}$, MnO delivered $\sim 150 \mathrm{~mA} \mathrm{~h} \mathrm{~g}^{-1}$ @ $1600 \mathrm{~mA} \mathrm{~g}^{-1}$, $\mathrm{CuFeO}_{2}$ delivered $\sim 280 \mathrm{~mA} \quad \mathrm{~h}^{-1}$ (a) $1416 \mathrm{~mA}^{-1}$, graphene@ $\mathrm{Fe}_{2} \mathrm{O}_{3}$ delivered $\sim 425 \mathrm{~mA} \mathrm{~h} \mathrm{~g}^{-1}$ @ $2000 \mathrm{~mA} \mathrm{~g}^{-1}$, and $\left(\mathrm{Co}_{0.2} \mathrm{Cu}_{0.2} \mathrm{Mg}_{0.2} \mathrm{Ni}_{0.2} \mathrm{Zn}_{0.2}\right) \mathrm{O}$ rock-salt HEO delivered $\sim 280 \mathrm{~mA} \mathrm{~h} \mathrm{~g}^{-1}$ @ $1000 \mathrm{~mA} \mathrm{~g}^{-1} \cdot \cdot^{\mathbf{1 5 , 6 2 - 6 4}}$ The great rate capability of the HESO electrode can be attributed to the increased electronic conductivity, since the metallic phases are distributed within the oxide after the first charge-discharge cycle (see Fig. 5). In addition, the multi-valence nature of the constituent elements in the HESO (see Fig. 3) promotes the formation of oxygen vacancies, as shown above, which are known to favor $\mathrm{Li}^{+}$ transport ${ }^{24}$ and thus high-rate charge-discharge capability.
The cycling stability of the HESO electrode was evaluated, and the data obtained at a charge-discharge rate of $500 \mathrm{~mA} \mathrm{~g}^{-1}$ for 200 cycles are shown in Fig. 7a. The electrode shows a capacity retention ratio of approximately $90 \%$ after the cycling. This value can translate to an average capacity fading rate of $0.05 \%$ per cycle. As also shown in the figure, the CE values are around $\sim 99 \%$ up to 200 cycles, indicating great cyclability of the electrode. Some capacity fluctuations were observed during the cycling, and this phenomenon was repeatedly found for multiple cells. This behavior is probably related to the structural changes of the HESO and has also been reported for a rock-salt type HEO in the literature. ${ }^{15}$ The detailed mechanism is not clear yet. The much better cycling stability of the HESO electrode, compared to that of traditional conversiontype oxide electrodes, ${ }^{65-68}$ is associated with the entropy stabilization effects that maintain the crystalline oxide framework during the lithiation and promote the recovery of the spinel
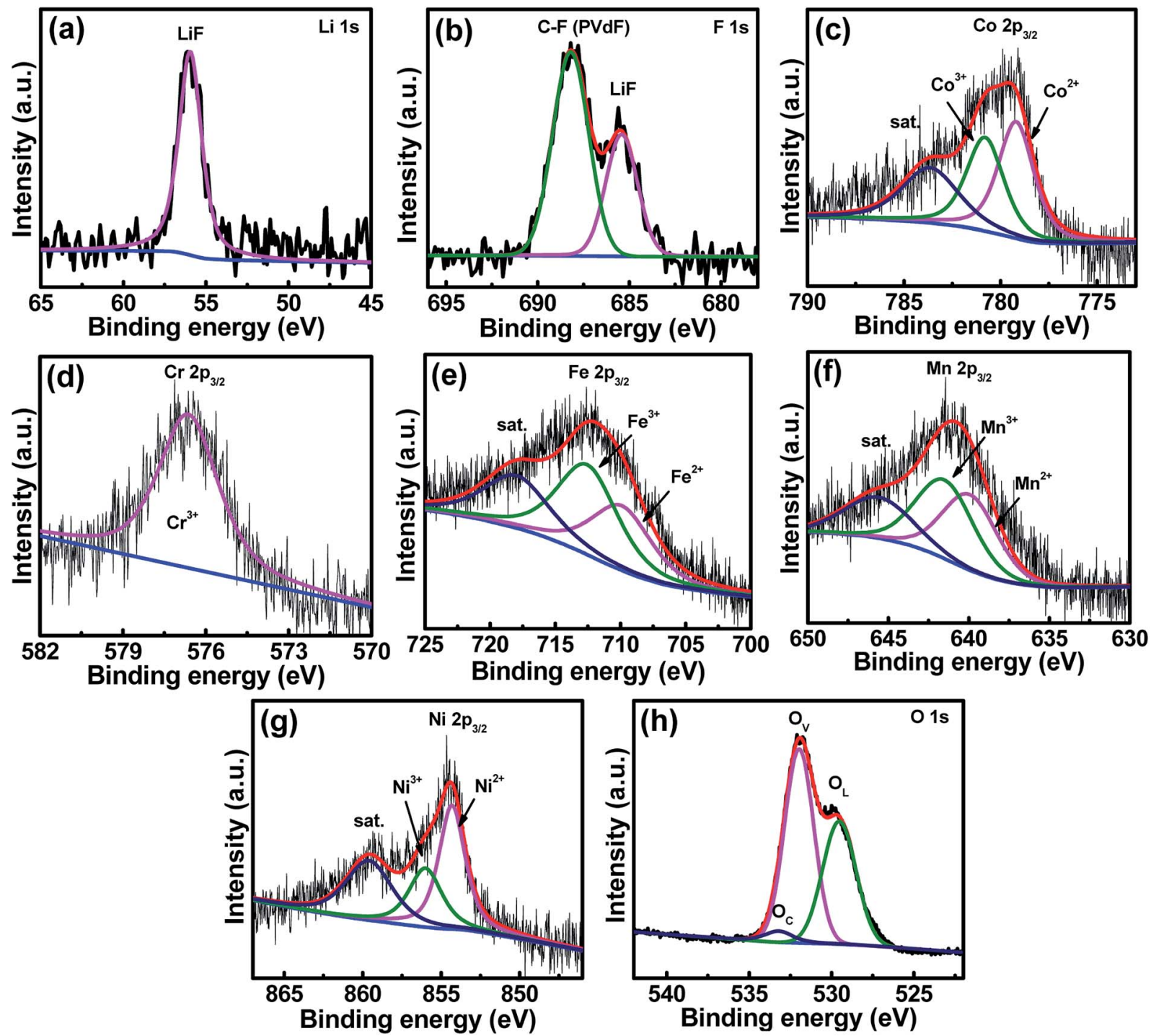

Fig. 8 XPS (a) Li 1s, (b) F 1s, (c) Co 2p, (d) Cr 2p, (e) Fe 2p, (f) Mn 2p, (g) Ni 2p, and (h) O 1s spectra of the HESO electrode after 70 charge-discharge cycles. 
phase during the delithiation. ${ }^{15}$ This assures the redox durability of the electrode.

To further examine the impedance characteristics of the HESO electrode, EIS measurements were performed. Fig. $7 \mathrm{~b}$ shows the spectra after various charge-discharge cycles. The Nyquist plots have intercepts at high frequencies, depressed semicircles at intermediate frequencies, and sloping lines at low frequencies. The equivalent circuit for these spectra is shown in the figure inset. $R_{\mathrm{e}}$ represents the electrolyte resistance, $R_{\mathrm{ct}}$ denotes the charge-transfer resistance between the active material and electrolyte, CPE is an interfacial constant phase element, and $W$ represents the Warburg impedance corresponding to $\mathrm{Li}^{+}$transport in the HESO electrode. As shown, the $R_{\mathrm{ct}}$ values are small, which explains the superior electrode rate capability. After the first charge-discharge cycle, the $R_{\mathrm{ct}}$ and $W$ values do not change significantly upon the SEI formation. This means a low-impedance SEI layer is formed. Moreover, the increased impedance due to the SEI formation may be compensated by the enhanced electronic conductivity of the electrode because of the formation of the metallic phase after the first delithiation. Besides, the apparent $\mathrm{Li}^{+}$diffusion coefficient in our HESO electrode calculated from the EIS data is 1.3 $\times 10^{-12} \mathrm{~cm}^{2} \mathrm{~s}^{-1}$, which is considerably higher than those of reported spinel oxide anodes, as shown in Fig. S4. $\dagger$ In contrast to the mostly used conversion-type oxide anodes, whose $R_{\mathrm{ct}}$ usually increases with cycling due to the agglomeration and pulverization of the active materials and the accumulation of the SEI film, ${ }^{69,70}$ in our case, the HESO electrode exhibits stable impedance characteristics up to 200 cycles. As shown in Fig. 7c, the $R_{\mathrm{e}}$ and $R_{\mathrm{ct}}$ values hardly increase with the cycle number. This explains the excellent capacity retention of this electrode after cycling.

In order to check the crystallinity of the HESO electrode after cycling (70 cycles), XRD analysis of the cycled electrode was carried out and the data are shown in Fig. S5. $\dagger$ The diffraction intensity of the cycled HESO electrode is low, indicating that the crystallinity reduces upon cycling. As shown in Fig. S6, $\uparrow$ the HRTEM and SAED data confirm the existence of the crystalline rock-salt structure. The STEM mapping results indicate that all the elements homogeneously distribute throughout the particles. Fig. 8a and b show the XPS Li 1s and F 1s spectra of the cycled electrode. The Li 1s spectrum reveals that the major form of $\mathrm{Li}$ in the SEI is LiF. The F 1s spectrum shows a strong peak at $\sim 688.0 \mathrm{eV}$ related to the PVDF binder and a characteristic LiF peak at $\sim 685.5 \mathrm{eV}$. These results reveal that LiF is an important component in the SEI film formed on the HESO electrode surface. As shown in Fig. 8c-g, divalent and trivalent states are seen for the $\mathrm{Co}, \mathrm{Fe}$, $\mathrm{Mn}$, and $\mathrm{Ni}$, whereas the $\mathrm{Cr}$ only shows a trivalent state. The $\mathrm{Co}^{2+} / \mathrm{Co}^{3+}, \mathrm{Fe}^{2+} / \mathrm{Fe}^{3+}, \mathrm{Mn}^{2+} / \mathrm{Mn}^{3+}$, and $\mathrm{Ni}^{2+} / \mathrm{Ni}^{3+}$ ratios are $56.5 /$ $43.5,46.4 / 53.6,49.1 / 50.9$, and $62.7 / 37.3$, respectively. It is noted that $\mathrm{Mn}^{4+}$ and $\mathrm{Cr}^{6+}$ were not found. This further confirms that the high-valence $\mathrm{Cr}^{6+}$ and $\mathrm{Mn}^{4+}$ cations found in the as-prepared HESO are related to surface oxidation. The $O$ 1s spectrum can be fitted into the $\mathrm{O}_{\mathrm{L}}, \mathrm{O}_{\mathrm{V}}$, and $\mathrm{O}_{\mathrm{C}}$ components. The fraction of the $\mathrm{O}_{\mathrm{V}}$ clearly increases after cycling. The ratio of $\mathrm{O}_{\mathrm{L}} / \mathrm{O}_{\mathrm{V}} / \mathrm{O}_{\mathrm{C}}$ is $40.5 / 55.7 / 3.8$.
Fig. S7a and $\mathrm{b} \dagger$ show the SEM morphologies of the electrode before and after 200 full charge-discharge cycles, respectively. Only a slight volume expansion of the HESO NPs was observed. No cracks (due to mechanical stress) and particle agglomeration, which are typical for the conventional conversion-type anodes, are seen on the cycled HESO electrode. For rock-salt (MgCoNiCuZn)O, it was found that after the first lithiation/delithiation cycle, even with inactive $\mathrm{MgO}$ stabilization, the structure almost disappeared, indicating the loss of crystalline ordering of the oxide. However, distinct XRD signals were clearly detected (see Fig. 5) for our HESO (with all cations being electroactive). This shows the role of the high entropy induced phase stabilization effects in the HESO. This is a unique feature of the HESO powder compared to the rock-salt HEOs reported previously. Due to the flexibility of filling the A and $B$ sites in the spinel structure, a larger number of combinations are expected, meaning increased entropy. This results in a stabilized structure without the use of dummy MgO. Even though further mechanism study and material optimization are needed, the HESO anode has shown great potential for future LIB applications.

\section{Conclusions}

A facile surfactant-assisted hydrothermal method has been used to synthesize single-phase HESO NPs for use as a LIB anode. Due to the existence of high valence states of the constituent cations and without the use of inactive $\mathrm{MgO}$ structural pillars, an extraordinary reversible charge-discharge capacity of $1235 \mathrm{~mA} \mathrm{~h} \mathrm{~g}^{-1}$ has been demonstrated. A unique lithiation-delithiation mechanism of the HESO electrode has been explored through ex situ XRD analysis. The distributed metallic phases and oxygen vacancies within the HESO electrode ensure the high electronic conductivity and fast $\mathrm{Li}^{+}$ transport, respectively, leading to the great high-rate performance of the electrode (i.e., $500 \mathrm{~mA} \mathrm{~h} \mathrm{~g}^{-1}$ @ $2000 \mathrm{~mA} \mathrm{~g}^{-1}$ ). The much better cycling stability of the HESO electrode $(90 \%$ capacity retention after 200 cycles), compared to that of conventional conversion-type oxide electrodes, is associated with the entropy stabilization effects that retain the crystalline oxide framework during lithiation and delithiation. The HESO NP anode opens a new window for the development of nextgeneration LIB electrode materials.

\section{Conflicts of interest}

There are no conflicts to declare.

\section{Acknowledgements}

This work has been supported by the Ministry of Science and Technology of Taiwan under Grant No MOST 107-2218-E-006047 and MOST 108-2218-E-006-023.

\section{References}

1 J. W. Yeh, S. K. Chen, S. J. Lin, J. Y. Gan, T. S. Chin, T. T. Shun, C. H. Tsau and S. Y. Chang, Adv. Eng. Mater., 2004, 6, 299-303. 
2 C. M. Rost, E. Sachet, T. Borman, A. Moballegh, E. C. Dickey, D. Hou, J. L. Jones, S. Curtarolo and J.-P. Maria, Nat. Commun., 2015, 6, 8485.

3 A. Sarkar, R. Djenadic, D. Wang, C. Hein, R. Kautenburger, O. Clemens and H. Hahn, J. Eur. Ceram. Soc., 2018, 38, 2318-2327.

4 S. Jiang, T. Hu, J. Gild, N. Zhou, J. Nie, M. Qin, T. Harrington, K. Vecchio and J. Luo, Scr. Mater., 2018, 142, 116-120.

5 A. Sarkar, R. Djenadic, N. J. Usharani, K. P. Sanghvi, V. S. Chakravadhanula, A. S. Gandhi, H. Hahn and S. S. Bhattacharya, J. Eur. Ceram. Soc., 2017, 37, 747-754.

6 J. Zhou, J. Zhang, F. Zhang, B. Niu, L. Lei and W. Wang, Ceram, 2018, 44, 22014-22018.

7 E. Castle, T. Csanádi, S. Grasso, J. Dusza and M. Reece, Sci. Rep., 2018, 8, 8609.

8 P. H. Mayrhofer, A. Kirnbauer, P. Ertelthaler and C. M. Koller, Scr. Mater., 2018, 149, 93-97.

9 J. Gild, Y. Zhang, T. Harrington, S. Jiang, T. Hu, M. C. Quinn, W. M. Mellor, N. Zhou, K. Vecchio and J. Luo, Sci. Rep., 2016, 6, 37946.

10 T. Jin, X. Sang, R. R. Unocic, R. T. Kinch, X. Liu, J. Hu, H. Liu and S. Dai, Adv. Mater., 2018, 30, 1707512.

11 C.-W. Tsai, S.-W. Lai, K.-H. Cheng, M.-H. Tsai, A. Davison, C.-H. Tsau and J.-W. Yeh, Thin Solid Films, 2012, 520, 2613-2618.

12 R.-Z. Zhang, F. Gucci, H. Zhu, K. Chen and M. J. Reece, Inorg. Chem., 2018, 57, 13027-13033.

13 A. Sarkar, Q. Wang, A. Schiele, M. R. Chellali, S. S. Bhattacharya, D. Wang, T. Brezesinski, H. Hahn, L. Velasco and B. Breitung, Adv. Mater., 2019, 1806236.

14 H. Chen, J. Fu, P. Zhang, H. Peng, C. W. Abney, K. Jie, X. Liu, M. Chi and S. Dai, J. Mater. Chem. A, 2018, 6, 11129-11133.

15 A. Sarkar, L. Velasco, D. Wang, Q. Wang, G. Talasila, L. de Biasi, C. Kübel, T. Brezesinski, S. S. Bhattacharya and H. Hahn, Nat. Commun., 2018, 9, 3400.

16 D. Bérardan, S. Franger, D. Dragoe, A. K. Meena and N. Dragoe, Phys. Status Solidi RRL, 2016, 10, 328-333.

17 J. Gild, M. Samiee, J. L. Braun, T. Harrington, H. Vega, P. E. Hopkins, K. Vecchio and J. Luo, J. Eur. Ceram. Soc., 2018, 38, 3578-3584.

18 K. Chen, X. Pei, L. Tang, H. Cheng, Z. Li, C. Li, X. Zhang and L. An, J. Eur. Ceram. Soc., 2018, 38, 4161-4164.

19 A. Sarkar, C. Loho, L. Velasco, T. Thomas, S. S. Bhattacharya, H. Hahn and R. Djenadic, Dalton Trans., 2017, 46, 1216712176.

20 J. Dąbrowa, M. Stygar, A. Mikuła, A. Knapik, K. Mroczka, W. Tejchman, M. Danielewski and M. Martin, Mater. Lett., 2018, 216, 32-36.

21 M. Stygar, J. Dạbrowa, M. Moździerz, M. Zajusz, W. Skubida, K. Mroczka, K. Berent, K. Świerczek and M. Danielewski, J. Eur. Ceram. Soc., 2020, 40, 1644-1650.

22 Z. Grzesik, G. Smoła, M. Miszczak, M. Stygar, J. Dąbrowa, M. Zajusz, K. Świerczek and M. Danielewski, J. Eur. Ceram. Soc., 2020, 40, 835-839.

23 D. Wang, Z. Liu, S. Du, Y. Zhang, H. Li, Z. Xiao, W. Chen, R. Chen, Y. Wang and Y. Zou, J. Mater. Chem. A, 2019, 7, 24211-24216.
24 D. Bérardan, S. Franger, A. Meena and N. Dragoe, J. Mater. Chem. A, 2016, 4, 9536-9541.

25 N. Qiu, H. Chen, Z. Yang, S. Sun, Y. Wang and Y. Cui, J. Alloys Compd., 2019, 777, 767-774.

26 Q. Wang, A. Sarkar, Z. Li, Y. Lu, L. Velasco, S. S. Bhattacharya, T. Brezesinski, H. Hahn and B. Breitung, Electrochem. Commun., 2019, 100, 121-125.

27 Q. Wang, A. Sarkar, D. Wang, L. Velasco, R. Azmi, S. S. Bhattacharya, T. Bergfeldt, A. Düvel, P. Heitjans and T. Brezesinski, Energy Environ. Sci., 2019, 12, 2433-2442.

28 C. Zhao, F. Ding, Y. Lu, L. Chen and Y. S. Hu, Angew. Chem., Int. Ed., 2020, 59, 264-269.

29 H. Chen, N. Qiu, B. Wu, Z. Yang, S. Sun and Y. Wang, RSC $A d v .$, 2020, 10, 9736-9744.

30 K. A. Jarvis, C.-C. Wang, A. Manthiram and P. J. Ferreira, J. Mater. Chem. A, 2014, 2, 1353-1362.

31 M. Chen, D. Chen, Y. Liao, X. Zhong, W. Li and Y. Zhang, ACS Appl. Mater. Interfaces, 2016, 8, 4575-4584.

32 B. S. Murty, J.-W. Yeh, S. Ranganathan and P. Bhattacharjee, High-entropy alloys, Elsevier, 2019.

33 P. W. Menezes, A. Indra, V. Gutkin and M. Driess, Chem. Commun., 2017, 53, 8018-8021.

34 G. Allen, S. Harris, J. Jutson and J. Dyke, Appl. Surf. Sci., 1989, 37, 111-134.

35 R. Ding, L. Qi, M. Jia and H. Wang, Nanoscale, 2014, 6, 13691376.

36 B. Bao, J. Liu, H. Xu, B. Liu, K. Zhang and Z. Jin, RSC Adv., 2017, 7, 8589-8597.

37 I. Grohmann, E. Kemnitz, A. Lippitz and W. Unger, Surf. Interface Anal., 1995, 23, 887-891.

38 J. Tang, S. Ni, Q. Chen, X. Yang and L. Zhang, J. Alloys Compd., 2017, 698, 121-127.

39 T. Yamashita and P. Hayes, Appl. Surf. Sci., 2008, 254, 24412449.

40 M. Oku and K. Hirokawa, J. Electron Spectrosc. Relat. Phenom., 1976, 8, 475-481.

41 M. Langell, C. Hutchings, G. Carson and M. Nassir, J. Vac. Sci. Technol., A, 1996, 14, 1656-1661.

42 X. Zheng, Y. Zhang, H. Liu, D. Fu, J. Chen, J. Wang, C. Zhong, Y. Deng, X. Han and W. Hu, Small, 2018, 14, 1803666.

43 J.-W. Kim, S. J. Lee, P. Biswas, T. I. Lee and J.-M. Myoung, Appl. Surf. Sci., 2017, 406, 192-198.

44 D. Li, Y. Gong, Y. Zhang, C. Luo, W. Li, Q. Fu and C. Pan, Sci. Rep., 2015, 5, 12903.

45 J. H. Kim, Y. J. Jang, J. H. Kim, J.-W. Jang, S. H. Choi and J. S. Lee, Nanoscale, 2015, 7, 19144-19151.

46 J. Bao, X. Zhang, B. Fan, J. Zhang, M. Zhou, W. Yang, X. Hu, H. Wang, B. Pan and Y. Xie, Angew. Chem., Int. Ed., 2015, 54, 7399-7404.

47 M.-P. Pileni, Nat. Mater., 2003, 2, 145.

48 S. Abouali, M. A. Garakani, Z.-L. Xu and J.-K. Kim, Carbon, 2016, 102, 262-272.

49 X. Fan, J. Shao, X. Xiao, L. Chen, X. Wang, S. Li and H. Ge, J. Mater. Chem. A, 2014, 2, 14641-14648.

50 F. Zou, Y.-M. Chen, K. Liu, Z. Yu, W. Liang, S. M. Bhaway, M. Gao and Y. Zhu, ACS Nano, 2015, 10, 377-386. 
51 N. Wang, X. Ma, Y. Wang, J. Yang and Y. Qian, J. Mater. Chem. A, 2015, 3, 9550-9555.

52 K. Xiao, L. Xia, G. Liu, S. Wang, L.-X. Ding and H. Wang, J. Mater. Chem. A, 2015, 3, 6128-6135.

53 C. Jo, W.-G. Lim, A. H. Dao, S. Kim, S. Kim, S. Yoon and J. Lee, J. Mater. Chem. A, 2017, 5, 24782-24789.

54 Y. Deng, S. Tang, Q. Zhang, Z. Shi, L. Zhang, S. Zhan and G. Chen, J. Mater. Chem., 2011, 21, 11987-11995.

55 H.-C. Liu and S.-K. Yen, J. Power Sources, 2007, 166, 478-484.

56 Y. Fu and A. Manthiram, Electrochim. Acta, 2013, 109, 716719.

57 Y. Li, B. Tan and Y. Wu, Nano Lett., 2008, 8, 265-270.

58 A. Manzoor, S. Pandey, D. Chakraborty, S. R. Phillpot and D. S. Aidhy, npj Comput. Mater., 2018, 4, 47.

59 Z. Lei, X. Liu, H. Wang, Y. Wu, S. Jiang and Z. Lu, Scr. Mater., 2019, 165, 164-169.

60 Y. Lu, L. Yu and X. W. D. Lou, Chem, 2018, 4, 972-996.

61 J. Cabana, L. Monconduit, D. Larcher and M. R. Palacin, Adv. Mater., 2010, 22, E170-E192.
62 S.-F. Zheng, J.-S. Hu, L.-S. Zhong, W.-G. Song, L.-J. Wan and Y.-G. Guo, Chem. Mater., 2008, 20, 3617-3622.

63 W. Zhou, J. Zhu, C. Cheng, J. Liu, H. Yang, C. Cong, C. Guan, X. Jia, H. J. Fan and Q. Yan, Energy Environ. Sci., 2011, 4, 4954-4961.

64 K. Zhong, X. Xia, B. Zhang, H. Li, Z. Wang and L. Chen, J. Power Sources, 2010, 195, 3300-3308.

65 L. Lu, J.-Z. Wang, X.-B. Zhu, X.-W. Gao and H.-K. Liu, J. Power Sources, 2011, 196, 7025-7029.

66 S. G. Mohamed, C.-J. Chen, C. K. Chen, S.-F. Hu and R.-S. Liu, ACS Appl. Mater. Interfaces, 2014, 6, 22701-22708.

67 G. Wang, Y. Chen, K. Konstantinov, M. Lindsay, H. Liu and S. Dou, J. Power Sources, 2002, 109, 142-147.

68 L. Zhou, D. Zhao and X. W. Lou, Adv. Mater., 2012, 24, 745748.

69 J. Li, S. Hwang, F. Guo, S. Li, Z. Chen, R. Kou, K. Sun, C.-J. Sun, H. Gan and A. Yu, Nat. Commun., 2019, 10, 2224.

70 M. H. Modarres, J. H.-W. Lim, C. George and M. De Volder, J. Phys. Chem. C, 2017, 121, 13018-13024. 